УДК 502.1:332:338.14

Полінкевич О.М., д.е.н., професор

Східноєвропейський національний університет імені Лесі Українки

\title{
ДІАГНОСТИКА ЕКОЛОГО-ЕКОНОМІЧНОЇ БЕЗПЕКИ ПІДПРИЄМСТВ В УКРӒ̈НI
}

У статті проведено діагностику еколого-економічної безпеки підприємств в Україні. Запропоновано використовувати систему показників, яка поєднує вимір таких змін, як соціально-психологічні, виробничо-технологічні, фінансово-економічні, інтелектуально-кадрові, структурно-адміністративні. Визначено перелік якісних та кількісних показників, що оцінюють ефективність змін у кожній із груп. Доведено, що потрібна розробка стратегії забезпечення еколого-економічної безпеки підприємств України.

Ключові слова: екологічна безпека, зміни, економічна безпека, показники діагностики, капітальні інвестиції, поточні витрати, рентабельність активів, фінансова стійкість, платоспроможність

Polinkevych O.

\section{ENVIRONMENTAL ECONOMIC SECURITY OF ENTERPRISES DIAGNOSIS IN UKRAINE}

The article deals with the diagnostics of ecological and economic security of enterprises in Ukraine. It is proposed to use a system of indicators that combines the measurement of such changes as socio-psychological, production-technological, financial-economic, intellectual-human, structural-administrative. The list of qualitative and quantitative indicators that evaluate the effectiveness of changes in each group is determined. It is proved that the development of a strategy for ensuring the ecological and economic security of Ukrainian enterprises is required.

Key words: environmental security, change, economic security, valuation indicators, capital investment, recurrent costs, asset return, financial sustainability, solvency.

\section{Полинкевич О.Н.}

\section{ДИАГНОСТИКА ЭКОЛОГО-ЭКОНОМИЧЕСКОЙ БЕЗОПАСНОСТИ ПРЕДПРИЯТИЙ В УКРАИНЕ}

В статье проведена диагностика эколого-экономической безопасности предприятий в Украине. Предложено использовать систему показателей, которая сочетает измерение таких изменений, как социально-психологические, производственно-технологические, финансово-экономические, интеллектуально-кадровые, структурно-административные. Определен перечень качественных и количественных показателей, оценивающих эффективность изменений в каждой из групп. Доказано, что требуется разработка стратегии обеспечения эколого-экономической безопасности предприятий Украины.

Ключевые слова: экологическая безопасность, изменения, экономическая безопасность, показатели диагностики, капитальные инвестиции, текущие расходы, рентабельность активов, финансовая устойчивость, платежеспособность.

Постановка проблеми у загальному вигляді і її зв'язок з важливим науковими та практичними завданнями. В кінці XX ст. на початку XXI ст. глобальна економічна система досягла тієї критичної точки, в якій екологічні проблеми призводять до зміни всієї парадигми розвитку суспільства. Сучасна ринкова система сформувалася ще до того, як екологічні загрози стали катастрофічними. Світова економіка не може вирішити екологічні проблеми. Це змушує суспільство шукати нові способи виживання. Вирішити екологічні проблеми неможливо, спираючись тільки на технологічні рішення, оскільки вони є одночасно природничо-науковими, соціальними, економічними та політичними. Міжнародну еколого-економічну політику розвинених країн відрізняють подвійні стандарти, екологічний імперіалізм і розміщення в країнах, що розвиваються забруднюючих виробництв. Значний рівень споживання в розвинених країнах $\epsilon$ головною причиною глобальних екологічних проблем. Основною причиною 
екологічних проблем у країнах, що розвиваються, є бідність, економічна відсталість, нерозвиненість екологічного законодавства, корумпованість місцевих чиновників. Діє принцип «спочатку розвиток, потім екологія», який знецінює досягнуті в ході економічного зростання результати [10].

Аналіз останніх досліджень, у яких започатковано вирішення проблеми. Проблеми еколого-економічної безпеки розкрито в працях багатьох дослідників. Більшість із них стосується визначення сутності та механізмів забезпечення екологічної безпеки, політичних чинників, впливу на підприємства. Учені пропонують різні підходи до вирішення цих проблем, а залежно від цього - різні механізми забезпечення екологоекономічної безпеки.

Вивченням економічної безпеки підприємства займалися такі вчені, як Г. Андрощук, Т. Васильців, О. Власюк, О. Барановський, В. Геєць, Л. Донець, В. Іванов, Я. Жаліло, М. Камлик, А. Козаченко, Г. Козаченко, О. Кизим, Ю. Лисенко, О. Ляшенко, А. Мокій, В. Мунтіян, О. Прокопенко, М. Петрушенко, Н. Реверчук, А. Черчик, Л. Черчик, С. Шкарлет та ін. Ними розроблено теоретико-методологічні засади оцінки економічної безпеки підприємства, обгрунтовано механізми й окремі інструменти управління економічною безпекою, виокремлено певні акценти та пріоритетні напрями забезпечення економічної безпеки підприємства.

А. Черчик подав власне визначення еколого-економічної безпеки підприємства як стану його захищеності від негативних впливів завдяки внутрішній стійкості, збереження самоідентичності й цілісності, гнучкості та адаптивності, що забезпечує спроможність до стабільного розвитку, реалізації поставлених цілей, досягнення бажаних результатів без нанесення шкоди оточенню, збереження природно-ресурсного й асиміляційного потенціалу довкілля [9]. Ним запропоновано оцінювати екологоекономічну безпеку підприємств через фінансову безпеку (коефіцієнт абсолютної ліквідності, оборотності оборотних засобів, фінансової стабільності), технікотехнологічну безпеку (коефіцієнт придатності основних засобів, матеріаловіддача, фондовіддача), кадрова безпека (коефіцієнт задоволення матеріальних потре персоналу, стабільності персоналу та безпечності від травматизму та професійних захворювань), а також блоку показників відновлення та використання лісових ресурсів, охоронної діяльності [8].

Міщук Є.В. проаналізувано вплив екологічної безпеки підприємства та його стейкхолдерів на їх економічну безпеку. Запропоновано типи екологічної безпеки. Показано, що при оцінюванні екологічної безпеки найчастіше використовуються категорії, що негативно відображаються на ії економічній безпеці. Виявлено, що маються також позитивні категорії, але в методиках оцінювання вони практично не враховуються. Указано на вплив екологічної безпеки підприємства та його стейкхолдерів на їх економічну безпеку через такі поняття як розвиток підприємства та його конкурентоспроможність. Запропоновано екологічну безпеку щодо підприємства та його стейкхолдерів вважати одним із нетрадиційних видів ресурсів підприємства. Удосконалено перелік економічних показників екологічної безпеки, до яких належать поточні витрат на охорону навколишнього середовища, екологічні платежі, капітальні витрати на ремонт основних засобів, екологічні вигоди від екологічних поліпшень, витрати, які підвищують екологічну та економічну ефективність [4, с. 87].

Л. Черчик розглянуто існуючі підходи до визначення сутності екологічної безпеки. Набули подальшого розвитку підходи до змістовного наповнення екологічної безпеки підприємства як стану захищеності від негативних впливів внутрішнього та зовнішнього середовища та здатності швидко усунути загрози, забезпечити своє функціонування на основі екологічно орієнтованих техніко-технологічних та управлінських інновацій, що унеможливлюють нанесення шкоди навколишньому природному середовищу, життю та здоров’ю людей. Відзначено, що екологічну безпеку підприємства доцільно розглядати 3 двох позицій: як захищеність довкілля, людей від негативного впливу діяльності підприємства та захищеність підприємства від екологічних загроз. Оскільки екологізація 
виробництва відображає довготермінові цілі розвитку підприємства, екологічну безпеку в системі менеджменту підприємства доцільно розглядати як критерій прийняття стратегічних рішень щодо: забезпечення відповідності усіх аспектів функціонування підприємств вимогам чинного екологічного законодавства та національних i міжнародних екологічних стандартів; забезпечення екологічного оздоровлення та відтворення порушених екосистем; використання екологобезпечних ресурсів та технологій; підготовки фахівців, які приймають екологовмотивовані управлінські рішення; використання в системі управління підприємствами екологічного менеджменту; формування ефективної системи інформаційно-аналітичного забезпечення управління екологічною безпекою [10].

Фещенко О.Л., Каменева Н.В. подано авторське визначення еколого-економічної безпеки підприємства як результату природоохоронної та відновлювальної діяльності, що сприяє виробленню дієвого теоретико-методичного підходу до оцінки й аналізу ступеня еколого-економічної безпеки підприємства залежно від масштабів і характеру заходів щодо захисту населення від екологічних загроз, що нанесено його діяльністю. Це визначення має важливе прикладне значення і $є$ необхідною умовою ефективного й екологічно безпечного функціонування підприємств у реаліях зростання масштабів екологічних проблем та супутніх їм економічних збитків, що обумовлює необхідність нових підходів до управління господарчою діяльністю промислових підприємств та служить дієвим інструментом для розробки збалансованих та ефективних управлінських рішень згідно із сучасними вимогами сталого розвитку [7].

Попри вагомі напрацювання вчених, динамічність розвитку економічних систем, їх оточення, технологій, сфери діяльності обумовлюють доцільність подальших досліджень, що визначає актуальність теми та цілі дослідження.

Цілі статті. Метою статті є діагностика еколого-економічної безпеки підприємств в Україні.

Виклад основного матеріалу дослідження 3 повним обгрунтуванням отриманих наукових результатів. Оцінка еколого-економічної безпеки, на нашу думку, повинна продемонструвати, по-перше, відповідність поточного стану підприємства цілям розвитку, які були визначені при обгрунтуванні стратегії забезпечення еколого-економічної безпеки, по-друге, поєднувати екологічну та економічну складові. При цьому, показники мають відповідати основним напрямам діяльності підприємств і демонструвати ефективність використання усіх ресурсів.

Діагностика повинні відповідати таким вимогам [10]:

- відображати мету i завдання оцінювання в короткотерміновому та довготерміновому періоді; динаміці;

- виражати сутність виробничих та еколого-економічних відносин в статиці та

- охоплювати усі сторони виробничо-господарської та екологічної діяльності підприємства;

- використовувати достовірні та репрезентативні еколого-економічні показники; забезпечувати порівнянність показників у часі та просторі для виконання контролю за діяльністю підприємства;

- вибір показників має визначатися метою оцінювання та інформаційною доступністю та містити мотиваційну складову для забезпечення екологоорієнтованого та економічно ефективного розвитку.

Етапами оцінювання еколого-економічної безпеки на короткотермінову перспективу $є$ [10]:

1) уточнення мети та завдань оцінки;

2) уточнення груп та підгруп показників, які будуть включені в аналіз та оцінку, відповідно до визначених завдань;

3) виявлення внутрішніх чинників еколого-економічної безпеки підприємств (по кожній $з$ підгруп); 
4) аналіз основних чинників, які впливають на рівень еколого-економічної безпеки підприємств;

5) оцінка еколого-економічної безпеки підприємства за ії̈ основними складовими (групами показників);

6) стандартизація показників;

7) визначення групових індексів;

8) визначення інтегрального індексу еколого-економічної безпеки підприємств;

9) визначення рівня еколого-економічної безпеки підприємств за встановленою шкалою або прийнятими критеріями (інтерпретація результатів оцінювання, перевірка їх достовірності та формулювання висновків).

Подамо систему оцінки еколого-економічної безпеки підприємства на рис. 1.

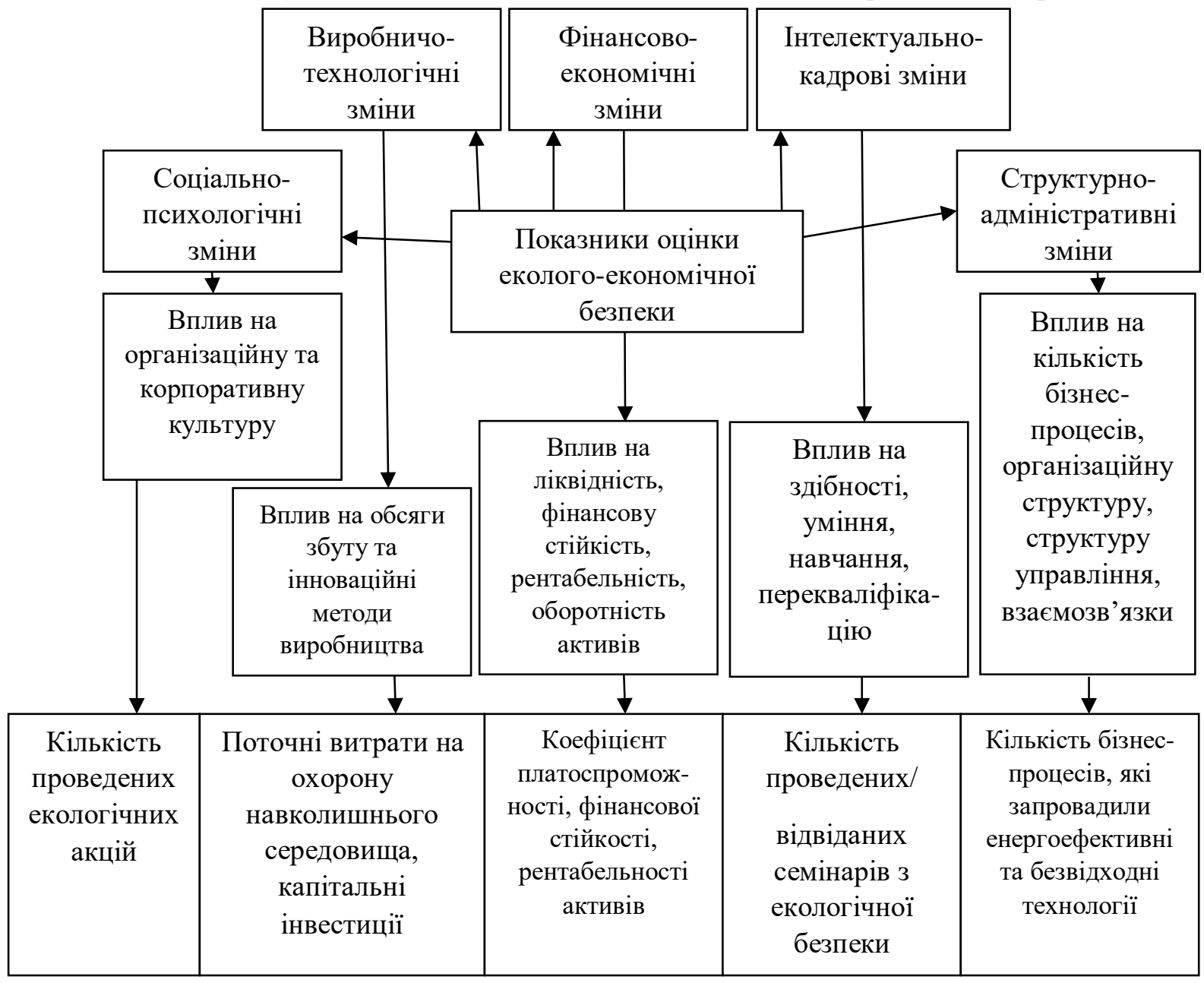

Рис. 1. Показники діагностики еколого-економічної безпеки підприємств через змін (розроблено автором)

Опишемо загальний стан еколого-економічної безпеки підприємств в Україні. Для цього побудуємо рис. 2-4 та таблиці 1-2. Капітальні інвестиції на охорону навколишнього природного середовища за видами природоохоронних заходів у фактичних цінах мали тенденцію до зростання у 2018 році порівняно з 2006 роком. Так, у 2006 році загальні капітальні інвестиції у 4,6 рази більше, на охорону атмосферного повітря і попередження змін клімату у 4,6 рази більше, на очищення зворотних вод у 2,2 рази більше, на поводження з відходами у 3,5 рази більше, на захист і реабілітацію грунту, підземних і поверхневих вод у 5,8 рази більше, на інші заходи у 33,8 рази більше 
проти 2018 року. Це є позитивною тенденцією, оскільки зростають капітальні інвестиції, які у майбутньому підвищать екологічну безпеку в Україні.

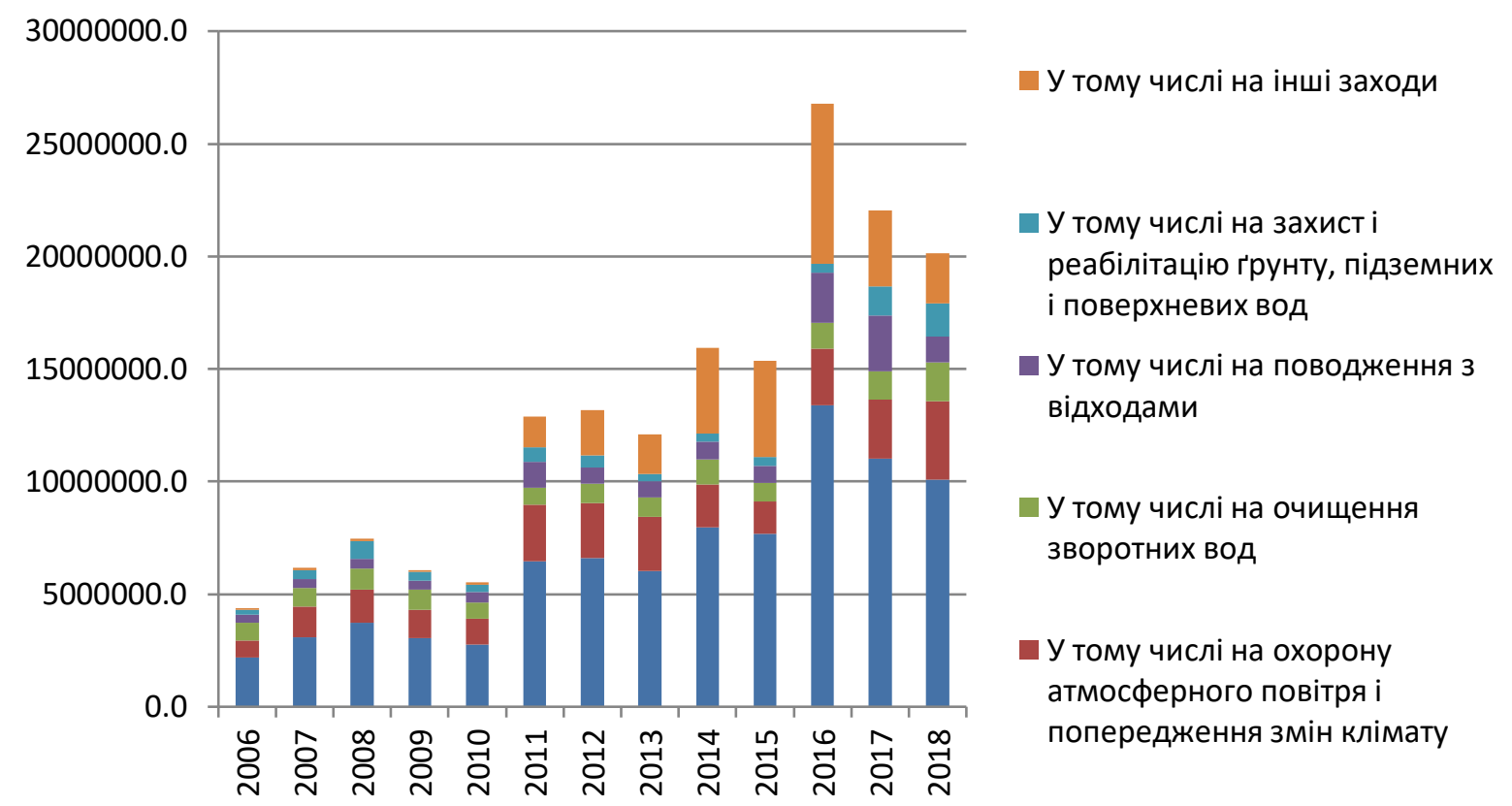

Рис. 2. Капітальні інвестиції на охорону навколишнього природного середовища за видами природоохоронних заходів у фактичних цінах, тис. грн (складено за [5])

Поточні витрати на охорону навколишнього природного середовища за видами природоохоронних заходів у фактичних цінах мають подібну динаміку.

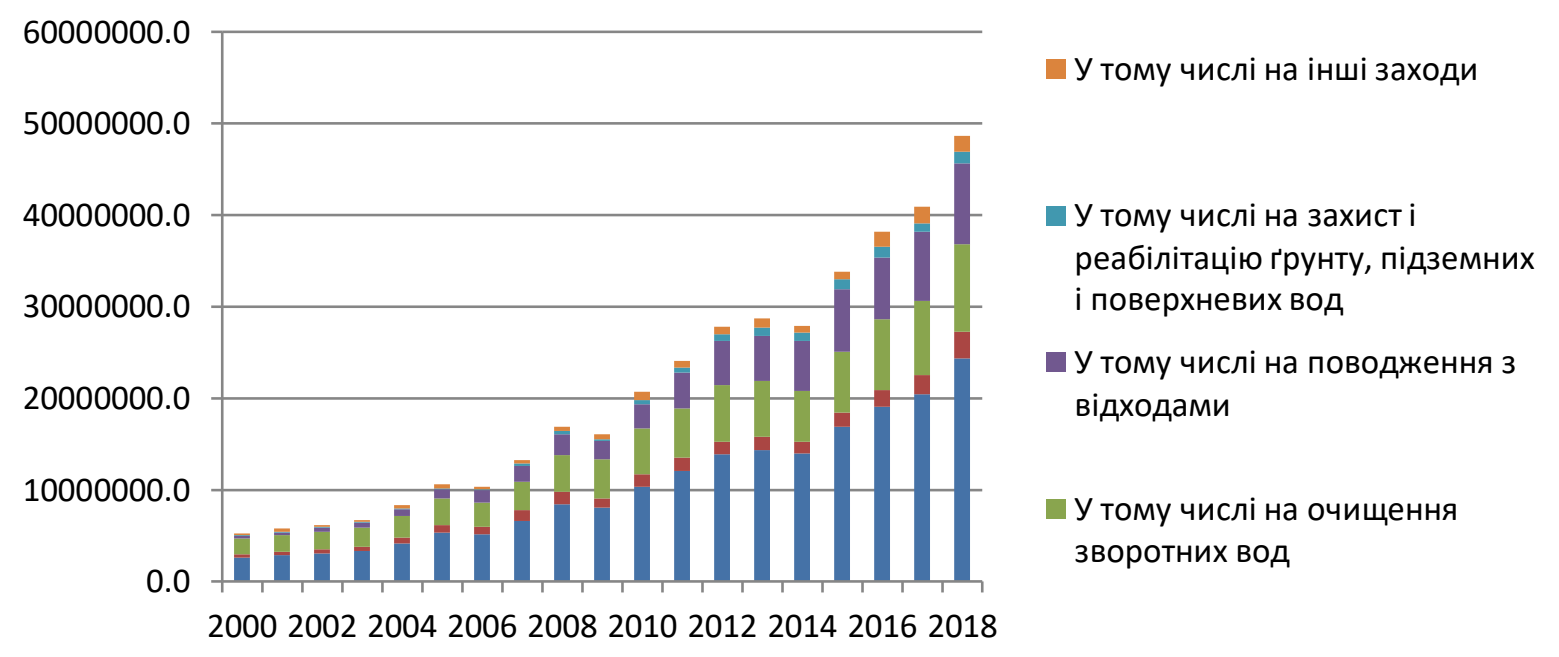

Рис. 3. Поточні витрати на охорону навколишнього природного середовища за видами природоохоронних заходів у фактичних цінах, тис. грн (складено за [5])

Так, у 2000 році загальні поточні витрати у 9,3 рази більше, на охорону атмосферного повітря і попередження змін клімату у 8,3 рази більше, на очищення зворотних вод у 5,6 рази більше, на поводження з відходами у 31,6 рази більше, на захист і реабілітацію грунту, підземних і поверхневих вод у 19,3 рази більше, на інші заходи у 8,1 рази більше проти 2018 року. Це є позитивною тенденцією, оскільки зростають поточні видатки, які у майбутньому підвищать екологічну безпеку в Україні. 
У таблицях 1-2 показано утворення відходів за видами економічної діяльності у 1995-2017 pp.

Таблиця 1.

Утворення відходів за видами економічної діяльності за 1995-2008 рр. (складено

\begin{tabular}{|l|c|c|c|c|c|c|c|c|c|c|}
\multicolumn{1}{c|}{ Показник } & 1995 & 2000 & 2001 & 2002 & 2003 & 2004 & 2005 & 2006 & 2007 & 2008 \\
\hline $\begin{array}{l}\text { Утворено відходів, } \\
\text { усього 1000т/ рік }\end{array}$ & 176400,2 & 184192,4 & 181963,7 & 203551,9 & 194221,4 & 214631,3 & 231189,5 & 288745,6 & 354703 & 278252,5 \\
\hline $\begin{array}{l}\text { Обсяг утворених } \\
\text { відходів від } \\
\text { економічної } \\
\text { діяльності на } \\
\text { одиницю ВВП у } \\
\begin{array}{l}\text { постійних цінах 2011 } \\
\text { року за ПКС, кг/1000 } \\
\text { дол. США }\end{array}\end{array}$ & 676,9 & 780,8 & 706,4 & 751,1 & 655,0 & 645,7 & 677,4 & 788,3 & 897,5 & 688,2 \\
$\begin{array}{l}\text { Частка відходів у } \\
\text { промисловості, \% }\end{array}$ & 75,94 & 93,29 & 93,18 & 89,16 & 92,38 & 93,24 & 93,70 & 92,36 & 95,18 & 94,01 \\
\hline $\begin{array}{l}\text { Частка відходів у } \\
\text { сільському, лісовому } \\
\text { та рибному } \\
\text { господарстві, \% }\end{array}$ & 0,36 & 0,68 & 0,88 & 1,02 & 0,99 & 1,16 & 1,12 & 1,12 & 0,89 & 1,14 \\
\hline $\begin{array}{l}\text { Частка відходів у } \\
\text { інших галузях, \% }\end{array}$ & 23,69 & 6,03 & 5,95 & 9,82 & 6,62 & 5,60 & 5,18 & 6,52 & 3,93 & 4,85 \\
\hline
\end{tabular}

Таблиця 2.

Утворення відходів за видами економічної діяльності за 2009-2017 рр. (складено

\begin{tabular}{|l|c|c|c|c|c|c|c|c|c|}
\hline \multicolumn{1}{|c|}{ Показник } & 2009 & 2010 & 2011 & 2012 & 2013 & 2014 & 2015 & 2016 & 2017 \\
\hline $\begin{array}{l}\text { Утворено відходів, усього } \\
\text { 1000т/ рік }\end{array}$ & 246381,7 & 422549,9 & 443795,5 & 446716,9 & 445262,1 & 355000,4 & 312267,6 & 295870,1 & 366054,0 \\
\hline $\begin{array}{l}\text { Обсяг утворених відходів } \\
\text { від економічної діяльності } \\
\text { на одиницю ВВП у } \\
\text { постійних цінах 2011 року } \\
\text { за ПКС, кг/1000 дол. США }\end{array}$ & 715,4 & 1177,3 & 1172,5 & 1177,4 & 1173,9 & 1001,4 & 977,4 & 904,2 & $\ldots$ \\
\hline $\begin{array}{l}\text { Частка відходів у } \\
\text { промисловості, \% }\end{array}$ & 93,66 & 93,51 & 91,66 & 92,60 & 92,93 & 93,55 & 92,50 & 91,78 & 94,50 \\
\hline $\begin{array}{l}\text { Частка відходів у } \\
\text { сільському, лісовому та } \\
\text { рибному господарстві, \% }\end{array}$ & 1,12 & 1,97 & 2,75 & 2,25 & 2,26 & 2,38 & 2,80 & 2,95 & 1,69 \\
\hline $\begin{array}{l}\text { Частка відходів у інших } \\
\text { галузях, \% }\end{array}$ & 5,21 & 4,53 & 5,59 & 5,15 & 4,81 & 4,07 & 4,70 & 5,27 & 3,81 \\
\hline
\end{tabular}

3 таблиць простежується тенденція до зростання утворення відходів у 2017 році проти 1995 року у 2,1 рази, обсяг утворених відходів від економічної діяльності на одиницю ВВП у постійних цінах 2011 року за паритетом купівельної спроможності зріс у 2016 році проти 1995 року в 1,3 рази. Найбільша частка за всіма роками припадає на промисловість. Вона зросла у 2017 році проти 1995 року в 1,2 рази, що є меншим показником, ніж у сільському, лісовому та рибному господарстві, де цей показник сягає 4,6 рази. Оте, у промисловості потрібно запроваджувати енергоефективні та безвідходні технології виробництва, що сприятиме екологічній безпеці підприємств України.

На рис. 4 подано динаміку викидів основних забруднюючих речовин на одиницю ВВП. 3 нього видно, що діоксид сірки на 1000 дол. США у 2017 році зменшився на 3,1 кг проти 1990 року, оксиди азоту на 0,4 кг, неметанові леткі органічні сполуки зросли на 0,2 кг у 2017 році проти 2004 року, аміаку зросли на 0,01 кг у 2017 році проти 1990 року, оксиду вуглецю зменшилися на 1,2 кг, загального обсягу зважених часток на 2,8 кг. Це $є$ 
позитивною динамікою, оскільки зменшуються викиди забруднюючих речовин на одиницю ВВП.

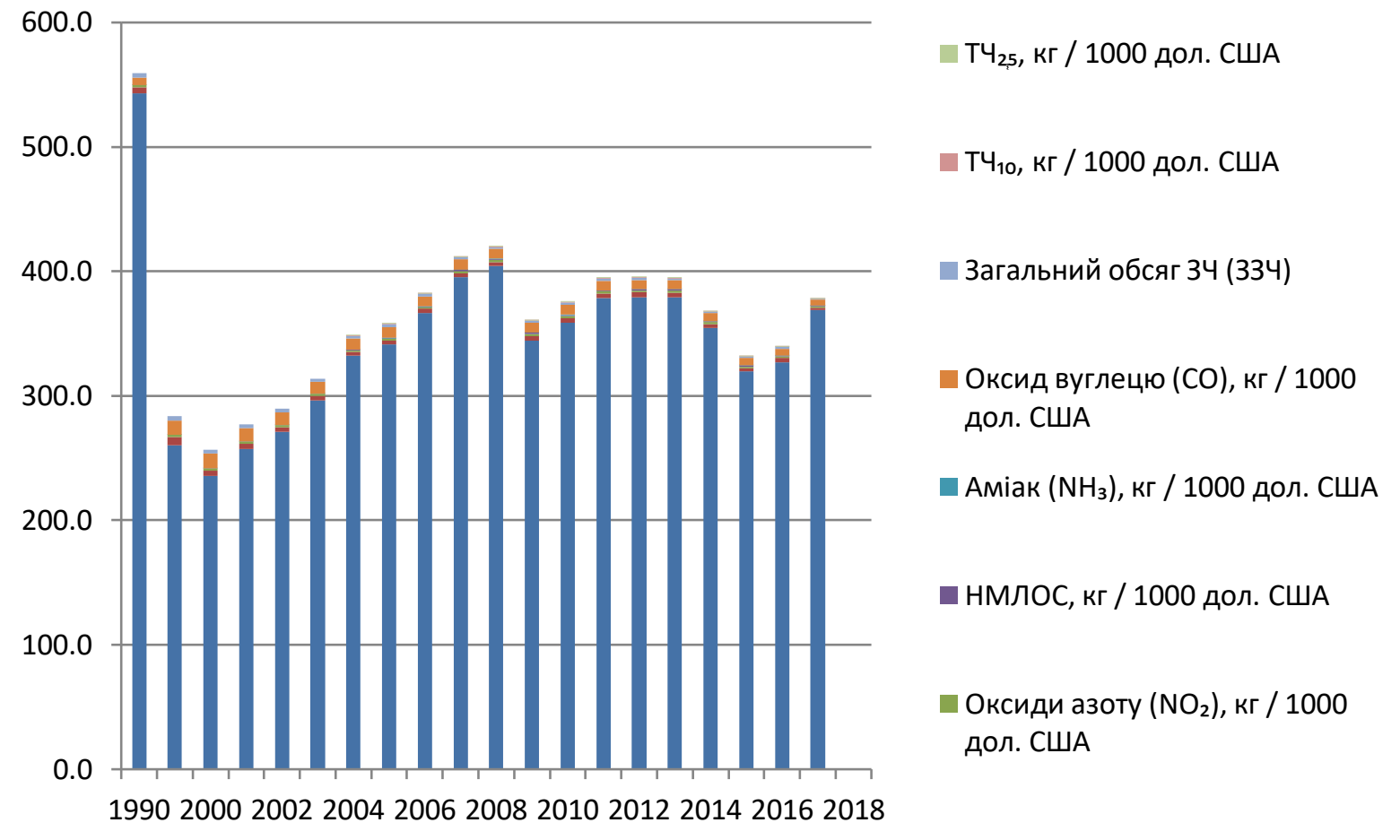

Рис. 4. Викиди основних забруднюючих речовин на одиницю ВВП (складено за [5]).

Визначимо основні показники економічної безпеки підприємств України у 20052018 pp. у табл. 3-4. 3 таблиць видно, що коефіцієнт платоспроможності відповідає мінімальному нормативному значенню $1-3$, проте бажаним $є$ величина $2-3$. Негативною $\epsilon$ тенденція до його зменшення, та невідповідність нормативному значенню у 2005, 2016, 2017, 2018 роках. Показник нижче нормативного свідчить про проблемний стан платоспроможності, адже оборотних активів недостатньо для того, щоб відповісти за поточними зобов'язаннями.

Таблиця 3.

Показники діагностики економічної безпеки підприємств України у 2005-2012 pp. (складено за [5])

\begin{tabular}{|l|c|c|c|c|c|c|c|c|}
\hline \multicolumn{1}{|c|}{ Показник } & 2005 & 2006 & 2007 & 2008 & 2009 & 2010 & 2011 & 2012 \\
\hline Оборотні активи, млн грн & 580156,4 & 899824 & 1226964 & 1665320 & 1893929 & 2229892,3 & 2584162,5 & 2921136 \\
\hline $\begin{array}{l}\text { Поточні зобов'язання, млн } \\
\text { грн }\end{array}$ & 626596,3 & 774536,9 & 1021608 & 1449432 & 1705408 & 1891268,2 & 2183258,9 & 2472842 \\
\hline $\begin{array}{l}\text { Коефіцієнт } \\
\text { платоспроможності }\end{array}$ & 0,93 & 1,16 & 1,20 & 1,15 & 1,11 & 1,18 & 1,18 & 1,18 \\
\hline Власний капітал, млн грн & 673005,7 & 801894,9 & 1050603 & 1133604 & 1269538 & 1426711,6 & 1586284,7 & 1904940 \\
\hline $\begin{array}{l}\text { Довгострокові } \\
\text { зобов'язання, млн грн }\end{array}$ & 136924,9 & 213669,7 & 350770,9 & 578515,6 & 608823,1 & 675619,4 & 774664 & 897223,9 \\
\hline $\begin{array}{l}\text { Коефіцієнт фінансової } \\
\text { стійкості }\end{array}$ & 0,55 & 0,55 & 0,56 & 0,53 & 0,51 & 0,51 & 0,50 & 0,52 \\
\hline Чистий прибуток, млн грн & 64370,8 & 76253,4 & 135897,9 & $-41025,1$ & $-37131,1$ & 13906,1 & 67797,9 & 35067,3 \\
\hline Валюта балансу, млн грн & 1477862 & 1842383 & 2494109 & 3245425 & 3676145 & 4096982,4 & 4676101,8 & 5419686 \\
\hline Рентабельність активів, \% & 4,36 & 4,14 & 5,45 & $-1,26$ & $-1,01$ & 0,34 & 1,45 & 0,65 \\
\hline
\end{tabular}


Таблиця 4.

Показники діагностики економічної безпеки підприємств України у 2013-2018 рр. (складено за [5])

\begin{tabular}{|l|c|c|c|c|c|c|}
\hline \multicolumn{1}{|c|}{ Показник } & 2013 & 2014 & 2015 & 2016 & 2017 & 2018 \\
\hline Оборотні активи, млн грн & 3069041,5 & 3271954 & 4108602,7 & 5772817 & 5650817,4 & 3350088,7 \\
\hline Поточні зобов’язання, млн грн & 2689338,2 & 3151253 & 4114903,2 & 5846689 & 5769539 & 3490408,3 \\
\hline Коефіцієнт платоспроможності & 1,14 & 1,04 & 1,00 & 0,99 & 0,98 & 0,96 \\
\hline Власний капітал, млн грн & 1950374,9 & 3271954 & 2288741,4 & 2445804 & 2458527,6 & 2018267,4 \\
\hline $\begin{array}{l}\text { Довгострокові зобов'язання, млн } \\
\text { грн }\end{array}$ & 1070722,1 & 1359925,7 & 1668158 & 1696871 & 1730977,4 & 1023606,6 \\
\hline Коефіцієнт фінансової стійкості & 0,53 & 0,77 & 0,49 & 0,41 & 0,42 & 0,47 \\
\hline Чистий прибуток, млн грн & $-22839,7$ & $-590066,9$ & $-373516,0$ & 29705,0 & 168752,8 & 293220,5 \\
\hline Валюта балансу, млн грн & 5712274,8 & 5994265,6 & 8073783,4 & 9991791 & 9961779,1 & 6532287,7 \\
\hline Рентабельність активів, \% & $-0,40$ & $-9,84$ & $-4,63$ & 0,30 & 1,69 & 4,49 \\
\hline
\end{tabular}

Це веде до зниження довіри до підприємств з боку кредиторів, постачальників, інвесторів і партнерів. Крім цього, проблеми з платоспроможністю ведуть до збільшення вартості позикових коштів i, як результат, до прямих фінансових втрат.

Коефіцієнт фінансової стійкості не відповідає нормативному значенню 0,7-0,9, окрім 2014 року. Негативно є тенденція до його зменшення у 2018 році проти 2005 року на 15 в.п. $47 \%$ активів підприємств фінансуються за рахунок постійного капіталу і довгострокових зобов'язань. Це говорить про те, що ризик банкрутства є високим.

Рентабельність активів мала стрибкоподібну динаміку. В окремі періоди діяльність підприємств була збитковою, зокрема у 2008, 2009, 2013-2015 роках. Іїі рівень $\epsilon$ вкрай низьким, близьким 4,5\% у 2018 році.

Висновки. Тобто, еколого-економічна безпека підприємств в Україні $\epsilon$ на низькому рівні та потребує розробки стратегії забезпечення еколого-економічної безпеки. Не сприяють ії підвищенню економічні показники, політична ситуація в країні. В екологічній безпеці варто констатувати пожвавлення через зростання капітальних інвестицій та поточних витрат на охорону навколишнього природного середовища, зменшення викидів основних забруднюючих речовин на одиницю ВВП. Промисловість займає перше місце за утворенням відходів серед видів економічної діяльності. Тому потрібна розробка стратегії збереження еколого-економічної безпеки підприємств України при розробці заходів із покращення ділового клімату та репутації підприємств у світовому економічному просторі.

\section{Список бібліографічного опису:}

1.Polinkevych O., Kamiński R. Corporate image in behavioral of business entities. Innovative Marketing. 2018. V.14, Issue 1. URL: http://dx.doi.org/10.21511/im.14(1).2018.04.

2.Євдомаха M.C. Політичні проблеми глобальної екологічної безпеки. URL: journals.iir.kiev.ua>index.php>pol_n>article>download (дата звернення 1.09.2019).

3.Ілляшенко O.B., Будрик O.I. Еколого-економічна безпека підприємства: теоретичні aспекти. URL: https://cutt.ly/lwHPaNE (дата звернення 23.07.2019).

4.Міщук Є.В. Вплив екологічної безпеки підприємства та його стейкхолдерів на їх економічну безпеку. Проблеми системного підходу в економіиі. 2018. Вип. 5 (67). С. 83-88.

5.Офіційні дані Державної служби статистики України. URL: http://www.ukrstat.gov.ua. (дата звернення 10.08.2019). 6.Процесне та соціально-компетентне управління інноваційним розвитком підприємницьких систем : монографія / за наук. ред. д-ра екон. наук, проф. О.М. Полінкевич. Луцьк: Вежа-Друк, 2017. 352 с.

7.Фещенко О.Л., Каменева Н.В. теоретичні засади визначення поняття еколого-економічної безпеки підприємства. Університетські наукові записки. 2017. № 61. С. 223-231

8.Черчик А. Методологічні аспекти оцінки еколого-економічної безпеки підприємств лісогосподарської сфери підприємства. Економічний часопис Східноєвропейського національного університету імені Лесі Украӥнки. 2017. № 1 (9). C. 90-95.

9.Черчик А. Наукові підходи до визначення сутності еколого-економічної безпеки підприємства. URL: https://er.knutd.edu.ua/bitstream/123456789/2906/1/20161102_410.pdf (дата звернення 14.08.2019).

10. Черчик Л. Екологічна безпека в системі менеджменту підприємства. Економічний часопис Східноєвропейського національного університету імені Лесі Украӥнки. 2019. № 1. С. 55-61.

\section{References:}

1.Polinkevych O., \& Kamiński R. (2018). Corporate image in behavioral of business entities. Innovative Marketing. 2018. V.14, Issue 1. Retrieved from: http://dx.doi.org/10.21511/im.14(1).2018.04. [in English]. 
2.Ievdomakha M.S. Politychni problemy hlobalnoi ekolohichnoi bezpeky [Political problems of global environmental security]. Retrieved from: journals.iir.kiev.uasindex.php>pol_n>article>download [in Ukrainian].

3.Illiashenko O.V., Budryk O.I. Ekoloho-ekonomichna bezpeka pidpryiemstva: teoretychni aspekty [Ecological and economic security of the enterprise: theoretical aspects]. Retrieved from: https://cutt.ly/lwHPaNE [in Ukrainian].

4.Mishchuk Ye.V. (2018). Vplyv ekolohichnoi bezpeky pidpryiemstva ta yoho steikkholderiv na yikh ekonomichnu bezpeku [Impact of environmental safety of the enterprise and its stakeholders on their economic security]. Problemy systemnoho pidkhodu v ekonomitsi [Problems of systematic approach in economy]. 2018. Vyp. 5 (67). pp. 83-88. [in Ukrainian].

5.Ofitsiini dani Derzhavnoi sluzhby statystyky Ukrainy [Official data of the State Statistics Service of Ukraine]. Retrieved from: http://www.ukrstat.gov.ua. [in Ukrainian].

6.Polinkevych, O.M. (Eds.) (2017). Protsesne ta sotsialno-kompetentne upravlinnia innovatsiinym rozvytkom pidpryiemnytskykh system [Process and socially competent management of innovative development of business systems] : monohrafiia. Lutsk: Vezha-Druk, 352 p. [in Ukrainian].

7.Feshchenko O.L., \& Kameneva N.V. (2017). Teoretychni zasady vyznachennia poniattia ekoloho-ekonomichnoi bezpeky pidpryiemstva [Theoretical basis for defining the concept of ecological and economic security of the enterprise.]. Universytetski naukovi zapysky [University research notes]. \# 61. pp. 223-231 [in Ukrainian].

8. Cherchyk A. (2017). Metodolohichni aspekty otsinky ekoloho-ekonomichnoi bezpeky pidpryiemstv lisohospodarskoi sfery pidpryiemstva [Methodological aspects of environmental and economic safety assessment of forestry enterprises.]. Ekonomichnyi chasopys Skhidnoievropeiskoho natsionalnoho universytetu imeni Lesi Ukrainky [Economic Journal of Lesya Ukrainka Eastern European National University]. \# 1 (9). pp. 90-95. [in Ukrainian].

9.Cherchyk A. Naukovi pidkhody do vyznachennia sutnosti ekoloho-ekonomichnoi bezpeky pidpryiemstva [Scientific approaches to determining the essence of ecological and economic security of the enterprise]. Retrieved from: https://er.knutd.edu.ua/bitstream/123456789/2906/1/20161102_410.pdf. [in Ukrainian].

10. Cherchyk L. (2019). Ekolohichna bezpeka v systemi menedzhmentu pidpryiemstva [Environmental safety in the enterprise management system]. Ekonomichnyi chasopys Skhidnoievropeiskoho natsionalnoho universytetu imeni Lesi Ukrainky [Economic Journal of Lesya Ukrainka Eastern European National University]. \# 1. pp. 55-61. [in Ukrainian].

\section{УДК 338.465 .2}

Потапюк І.П., к.е.н., доцент

Дюкарєв Д.С., аспірант

Полтавська державна аграрна академія

\section{ОНТОЛОГІЯ РОЗВИТКУ ВИДІВ І ФОРМ АУТСОРСИНГУ}

Стаття присвячена теорії управління підприємством на засадах аутсорсингу, а саме онтології розвитку його видів і форм. Досліджено та узагальнено порівняльну характеристику наукових підходів до класифікації аутсорсингу. Розглянуто та проаналізовано основні підходи до систематизації форм аутсорсингової діяльності.

Ключові слова: аутсорсинг, передача функцій, аутсорсинг бізнес-процесів, виробничий аутсорсинг, ІТ-аутсорсинг.

Potapiuk I., Diukariev D.

\section{ONTOLOGY OF DEVELOPMENT OF TYPES AND FORMS OF OUTSOURCING}

The article is devoted to the theory of enterprise management based on outsourcing, namely the ontology of development of its types and forms. The comparative characteristic of scientific approaches to the classification of outsourcing has been investigated and summarized. The basic approaches to systematization of forms of outsourcing activity are considered and analyzed.

Keywords: outsourcing, outsourcing, business process outsourcing, industrial outsourcing, IT-outsourcing.

Потапюк И.П., Дюкарев Д.С.

\section{ОНТОЛОГИЯ РАЗВИТИЯ ВИДОВ И ФОРМ АУТСОРСИНГА}

Статья посвящена теории управления предприятием на основе аутсорсинга, а именно онтологии развития его видов и форм. Исследованно и обобщенно сравнительную характеристику научных подходов к классификации аутсорсинга. Рассмотрены и проанализированы основные подходы к систематизации форм аутсорсинговой деятельности.

Ключевые слова: аутсорсинг, передача функций, аутсорсинг бизнес-процессов, производственный аутсорсинг, ИТ-аутсорсинг. 